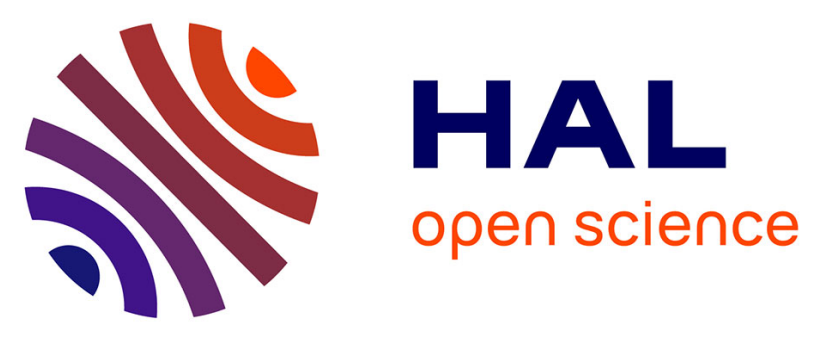

\title{
A single width-discharge regime relationship for individual threads of braided and meandering rivers from the Himalayan Foreland
}

Kumar Gaurav, S K Tandon, Olivier Devauchelle, Rajiv K Sinha, François Métivier

\section{To cite this version:}

Kumar Gaurav, S K Tandon, Olivier Devauchelle, Rajiv K Sinha, François Métivier. A single widthdischarge regime relationship for individual threads of braided and meandering rivers from the Himalayan Foreland. Geomorphology, 2017, 295, pp.126-133. 10.1016/j.geomorph.2017.07.004 . hal01571299

\author{
HAL Id: hal-01571299 \\ https://hal.science/hal-01571299
}

Submitted on 2 Aug 2017

HAL is a multi-disciplinary open access archive for the deposit and dissemination of scientific research documents, whether they are published or not. The documents may come from teaching and research institutions in France or abroad, or from public or private research centers.
L'archive ouverte pluridisciplinaire $\mathbf{H A L}$, est destinée au dépôt et à la diffusion de documents scientifiques de niveau recherche, publiés ou non, émanant des établissements d'enseignement et de recherche français ou étrangers, des laboratoires publics ou privés. 


\title{
A single width-discharge regime relationship for individual threads of braided and meandering rivers from the Himalayan Foreland
}

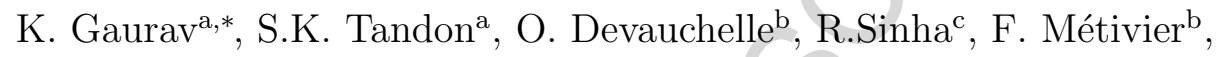 \\ ${ }^{a}$ Indian Institute of Science Education and Research, Bhopal, M.P, India \\ ${ }^{b}$ Institute de Physique du Globe de Paris, 1 Rue Jussieu, 75005 Paris cedex 05, France \\ ${ }^{c}$ Indian Institute of Technology, Kanpur, U.P, India
}

\begin{abstract}
We explore the existence of a single width-discharge regime relation for alluvial rivers of braided and meandering patterns. The study relies on the field measurement of a channel's cross section geometry (width, depth), discharge, and grain size of 98 individual threads of braided and meandering rivers from the Ganga-Brahmaputra plains of the Himalayan Foreland. Using this data set, we show that, irrespective of the diverse climatic and geologic setting along the strike, the braided and meandering threads share statistically indistinguishable regime relations and scale according to Lacey's law. To explain the observed trend in this empirical relationship, we use the threshold theory introduced by Glover and Florey (1951). Using this theory we detrend our data with respect to discharge to produce a statistically homogeneous ensemble of width measurements. The statistical distribution of the detrended width is similar for braided and meandering threads of the entire plains of
\end{abstract}

\footnotetext{
*Kumar Gaurav

Email address: kgaurav@iiserb.ac.in (K. Gaurav)
} 
the Foreland. This suggests that when we decompose a braided river into individual threads, each of these resemble single-thread meandering rivers. Based on this study, we conclude that the individual threads of braided and meandering rivers of the Himalayan Foreland are geometrically comparable and share a common width-discharge regime relation.

Keywords: Ganga Plain; regime relation; Lacey's law; threshold theory

\section{Introduction}

Alluvial rivers carve their channels in the sediments they carry and, in turn, these channels guide their flow. The interaction between sediment transport and water flow in river channels determines the course of alluvial landscape evolution and the resulting landform morphologies. Usually, rivers with high sediment transport rates develop a network of intertwined threads to produce a braided pattern. In contrast, at low or negligible sediment transport, these rivers typically flow through a well-defined single channel and form a sinuous meandering channel. In planform view, braided and meandering rivers appear to be very different from each other. In addition to sediment supply rate, other factors such as bank cohesion, riparian vegetation, bed sediment grain size, and longitudinal slope influence the formation of multithread, braided or single-thread, meandering rivers. Based on the field measurements of longitudinal slope and discharge, Leopold and Wolman (1957) showed that braided channels are separated from meandering channels by a critical value of the slope $(S)$ that decreases with water discharge $(Q)$ according to $S=0.06 Q^{-0.44}$ (discharge in $\mathrm{ft}^{3} \mathrm{~s}^{-1}$ ). 
Latrubesse (2008) pointed out that the relationship obtained by Leopold and Wolman is only valid for small rivers $\left(Q<400 \mathrm{~m}^{3} \mathrm{~s}^{-1}\right)$; it is not sensitive enough to discriminate channel patterns for large rivers having discharges $>1000 \mathrm{~m}^{3} \mathrm{~s}^{-1}$.

Eaton et al. (2010) differentiated braided and meandering channels based on their aspect ratio (width/depth). They found that channels with an aspect ratio $>50$ are prone to destabilization by mid-channel bars, which turn them into braids.

Tal and Paola (2007) and Braudrick et al. (2009) showed experimentally that riparian vegetation strengthens the banks of rivers, which lead to the transformation from initial braided pattern to meandering rivers thus maintaning single channel. According to Schumm et al. (1987), Smith (1998), and Parker et al. (2007), bank cohesion plays an important role in the initiation of meandering.

These studies show that boundary conditions influence the initiation of braiding and meandering. They do not inform us about the channel morphologies of fully developed rivers.

To study the morphology of single-thread alluvial rivers, Leopold and Maddock (1953) introduced the concept of hydraulic geometry. Mathematically, it translates into functional power-law relationships that relate width $(W)$, average depth $(H)$, and slope $(S)$ to water discharge $(Q)$ :

$$
\begin{gathered}
W=\alpha_{W} Q^{\beta_{W}} \\
H=\alpha_{H} Q^{\beta_{H}} \\
S=\alpha_{S} Q^{-\beta_{S}}
\end{gathered}
$$


where the coefficients $\alpha_{W}, \alpha_{H}$, and $\alpha_{S}$ and exponents $\beta_{W}, \beta_{H}$, and $\beta_{S}$ are numerical constants. Remarkably, the exponents in Eqs. (1), (2), and (3) are comparable for many single-thread rivers from distinct locations (Mosley, 1983; Parker et al., 2007; Métivier and Barrier, 2012; Métivier et al., 2016). Among these, the most famous is that of a river's width $\left(\beta_{W}\right)$, which is always close to 0.5 (Lacey, 1930). To explain Lacey's law, Glover and Florey (1951) introduced the concept of the threshold channel (Henderson, 1963; Seizilles et al., 2013). In such channels, the balance between gravity and fluid friction maintains the sediment at threshold everywhere on the bed surface. For a given discharge, this mechanism sets the shape and size of a single-thread alluvial channel.

If one assumes a braided river to be a collection of individual threads, then the question arises as to whether their morphology is comparable to those of single-thread meandering channels. In a recent study, Gaurav et al. (2014) compared the threads of sandy braided and meandering rivers on the alluvial fan of the Kosi River, India. They found that the widths of braided threads compare with that of meandering ones and exhibit a similar scaling law when plotted against water discharge. Métivier et al. (2015) found similar results for gravel-bed, braided, and meandering threads on the Bayanbulak Grassland, Tianshan, P.R. China. A significant inference from these studies is that the threads of braided and meandering rivers obey Lacey's law, which states that the width of a single-thread alluvial river is proportional to the square root of the discharge (Lacey, 1930). These results from two distinct regions suggest a common physical origin for the threads of braided and meandering rivers. However, any generalisation in this direction requires 
more extensive data from different geologic and climatic settings.

To further evaluate the findings of Gaurav et al. (2014) and Métivier et al. (2015), we compared the morphology of threads of braided and meandering rivers located in the large alluvial plains $\left(25,000 \mathrm{~km}^{2}\right)$ of the Ganga and Brahmaputra rivers (Fig. 1). The Ganga Plain consists of numerous braided and meandering channels that make up a large enough sample for this comparison. Also, this large alluvial plain includes diverse climatic regimes, riparian vegetation, and rainfall pattern.

The western part, known as the West Ganga Plain (WGP) receives less rainfall $(60-140 \mathrm{~cm})$ than the East Ganga Plain (EGP; 90-160 cm) and the Brahmaputra Plain (250-510 cm) (Dhar and Nandargi, 2000; Jain and Sinha, 2003; Sinha et al., 2005). As a consequence, the rivers of the WGP and the EGP exhibit varied morphological, hydrological, and sediment transport characteristics. The major rivers in the WGP show a high variation in their average suspended sediment load, ranging from $14 \mathrm{Mt} / \mathrm{yr}$ in the Ganga River to $125 \mathrm{Mt} / \mathrm{yr}$ in the Ghaghra River (Jain and Sinha, 2003). Moreover, most channels are incised (10-20 m). Conversely, the EGP rivers (the Kosi River alone carries about $193 \mathrm{Mt} / \mathrm{yr}$ ), are shallow, highly mobile, and extensively braided in their proximal part (Sinha and Friend, 1994; Sinha et al., 2005). These unique characteristics of the Himalayan Foreland allows us to explore the existence, if any, of a commonly applicable width-discharge regime relationship for the threads of braided and meandering rivers in diverse geomorphic settings. This would be a step toward the estimation of discharge in braided or meandering rivers based on a single width-discharge regime equation (Hedman and Osterkamp, 1982; Bjerklie et al., 2005; Ashmore and 
Sauks, 2006; Marcus and Fonstad, 2008; Smith and Pavelsky, 2008; Hirpa et al., 2013; Gleason and Smith, 2014; Pavelsky, 2014)

Here we report the measurement of width, discharge, and grain size of braided and meandering threads in the Ganga and Brahmaputra plains. After a description of the study area and of the measurement procedure, we compare the widths of the threads from our data set against their corresponding discharges. Then we use the threshold theory to detrend our measurements from the influence of discharge and generate a homogeneous ensemble from threads that are broadly distributed in size (Glover and Florey, 1951; Henderson, 1963; Seizilles et al., 2013; Gaurav et al., 2014; Métivier et al., $2015,2016)$. This ensemble finally allows us to compare the detrended width of braided and meandering threads of a large part of the Himalayan Foreland.

\section{Study area}

The Ganga Plain is the surface of the Himalayan Foreland basin. It is one of the world's largest areas of Tertiary and Quaternary alluvial sedimentation (Fig. 1; Burbank et al., 1996). This arc-shaped structure extends from the Himalaya in the north to the craton of central India in the south and from the Indus Plain in the west to the Brahmaputra Plain in the east. The Ganga Plain covers an area of about $250,000 \mathrm{~km}^{2}$ and extends for about $1000 \mathrm{~km}$ from west to east and between 200 and $450 \mathrm{~km}$ from north to south (Gansser, 1964; Singh, 1996).

The Ganga sedimentary basin is limited to the west and east by structural ridges: the Aravalli-Delhi Ridge and the Monghyr-Saharsa Ridge (Fig. 2; Geddes, 1960; Jain and Sinha, 2003). Furthermore, the basin is divided into 


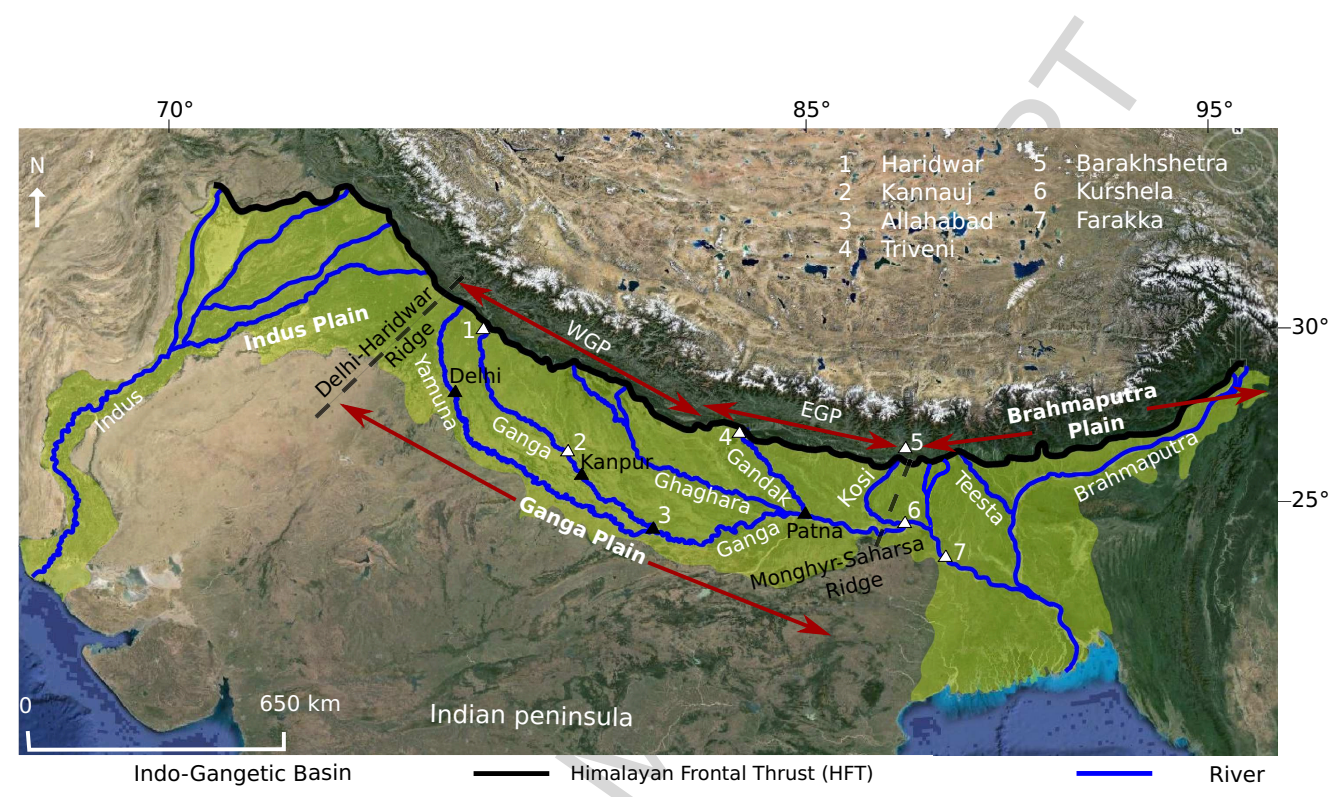

Fig. 1 Schematic of Indo-Gangetic plain shown on top of the Google Earth image https://www.google.com/earth/.

two sub basins, the West Ganga Plain (WGP) and the East Ganga Plain (EGP), by a third ridge, the Faizabad Ridge (Fig. 2; Rao, 1973; Valdiya, 1976).

The Ganga Plain is an area of active sedimentation that stores a large amount of Himalayan-derived sediments, mainly transported and deposited by the rivers Yamuna, Ganga, and their tributaries. For instance, the Ganga River carries more than 700 million tons of suspended sediments each year (Table 1; Métivier and Gaudemer, 1999; Sinha et al., 2005).

The present-day Ganga Plain can be considered as a flat alluvial surface. The slope of the Ganga River is of the order of $1.3 \cdot 10^{-4}$. In the eastern Ganga Plain, the longitudinal slope of the Kosi River varies from $8.5 \cdot 10^{-4}$ to $6.5 \cdot 10^{-5}$ (Singh, 1996; Gaurav et al., 2014).

The climate of the WGP and the EGP is highly variable. The rivers 
flowing in the WGP and the EGP have varied morphological, hydrological, and sediment transport characteristics. Table 1 reports typical values for the drainage area, the discharge, and the sediment load of rivers from both parts of the Ganga Plain, and Fig. 2 shows typical examples of streams from both areas.

The WGP streams are mildly braided (braiding index 1.3-1.6) to meandering (sinuosity index $>1.2$ ) and are less mobile. The major rivers (i.e., Ganga, Yamuna) in the WGP carry an average suspended sediment load of about 14 and 125 million tons per year respectively (Jain and Sinha, 2003). Furthermore, most channels are incised (about 10-20 $\mathrm{m}$ for the Ganga at Kanpur and the Yamuna River at Kalpi, Figs. 2B1 and B2). In contrast, the EGP rivers are shallow, highly mobile, highly braided in their upstream part, and carry much sediment (Sinha and Friend, 1994; Sinha et al., 2005). The Kosi and Gandak rivers of the EGP carry, on average, about 193 and 82 Mt/yr of average suspended sediment load (Jain and Sinha, 2003). Figure 2 shows an example of such streams.

Rivers flowing in the Ganga Plain are usually grouped into three types according to their catchment characteristics: plain-fed, foothill-fed, and mountainfed (Sinha and Friend, 1994).

These types exhibit distinct morphological, hydrological, and sediment transport characteristics (Sinha and Friend, 1994; Jain and Sinha, 2003). Plains-fed rivers originate in the plain itself, are fed by groundwater from the alluvium, and are highly meandering. Foothill-fed rivers originate from the Himalayan Piedmont. These are mainly fed by rainfall as opposed to snowmelt, and their morphology ranges from braided upstream to meander- 
Table 1 Hydrological characteristics of WGP and EGP rivers (Sinha et al., 2005). See Fig. 1 for the location of measurement stations.

\begin{tabular}{|c|c|c|c|c|c|}
\hline Id & Station & River & $\begin{array}{c}\mathrm{A}^{\mathrm{a}} \\
\left(\mathrm{km}^{2}\right)\end{array}$ & $\begin{array}{l}\mathrm{Q}_{\mathrm{Av}} \mathrm{b} \\
\left(\mathrm{m}^{3} / \mathrm{s}\right)\end{array}$ & $\begin{array}{c}\mathrm{Q}_{\mathrm{s}}{ }^{\mathrm{c}} \\
(\mathrm{Mt} / \mathrm{yr})\end{array}$ \\
\hline \multicolumn{6}{|c|}{ WGP } \\
\hline 1 & Haridwar & Ganga & 95,500 & 757 & 14 \\
\hline 2 & & Ganga & 240,000 & 1252 & 14.5 \\
\hline 3 & Allahabad & Yamuna & 358,000 & 4820 & 228 \\
\hline \multicolumn{6}{|c|}{ EGP } \\
\hline 4 & veni & Gandak & 37,845 & 1,529 & 79 \\
\hline 5 & arakhshetra & Kosi & 59,550 & 1,681 & 95 \\
\hline 6 & Kurshela & Kosi & 95,156 & 1,792 & 193 \\
\hline 7 & Farakka & Ganga & $6,48,000$ & 14,555 & 729 \\
\hline
\end{tabular}

${ }^{a}$ Catchment area, ${ }^{b}$ Average discharge, ${ }^{c}$ Average sediment load. 


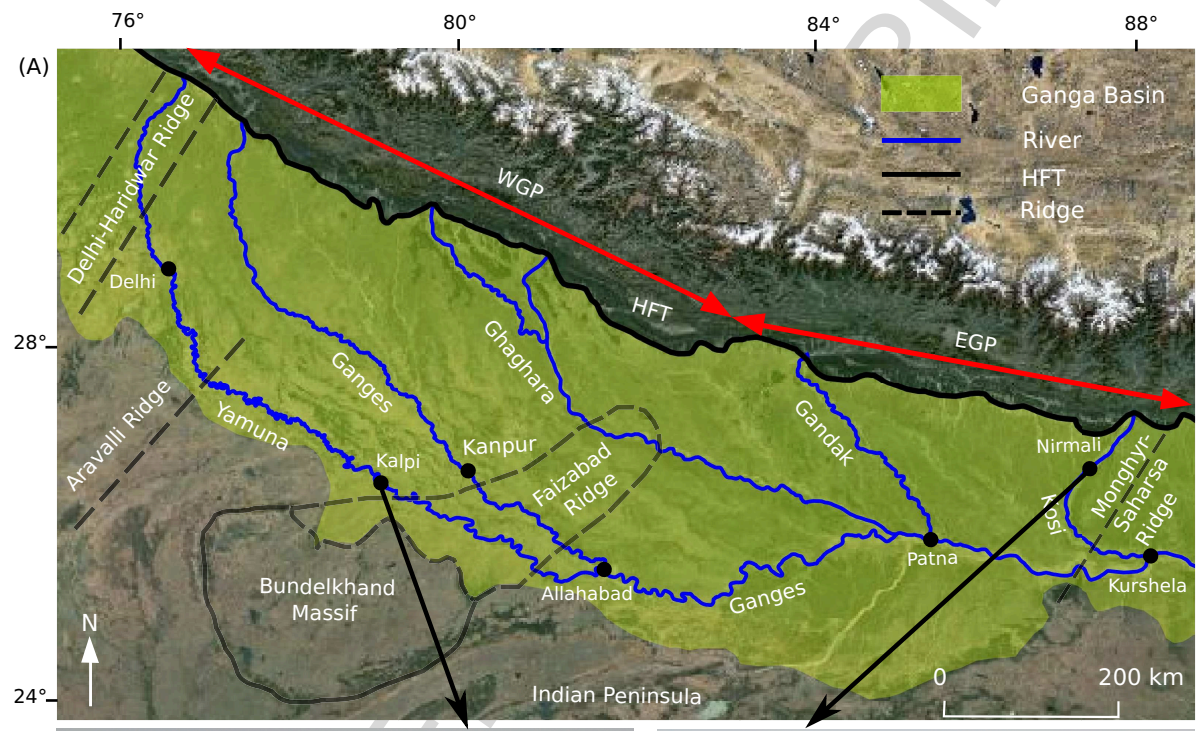

(B)
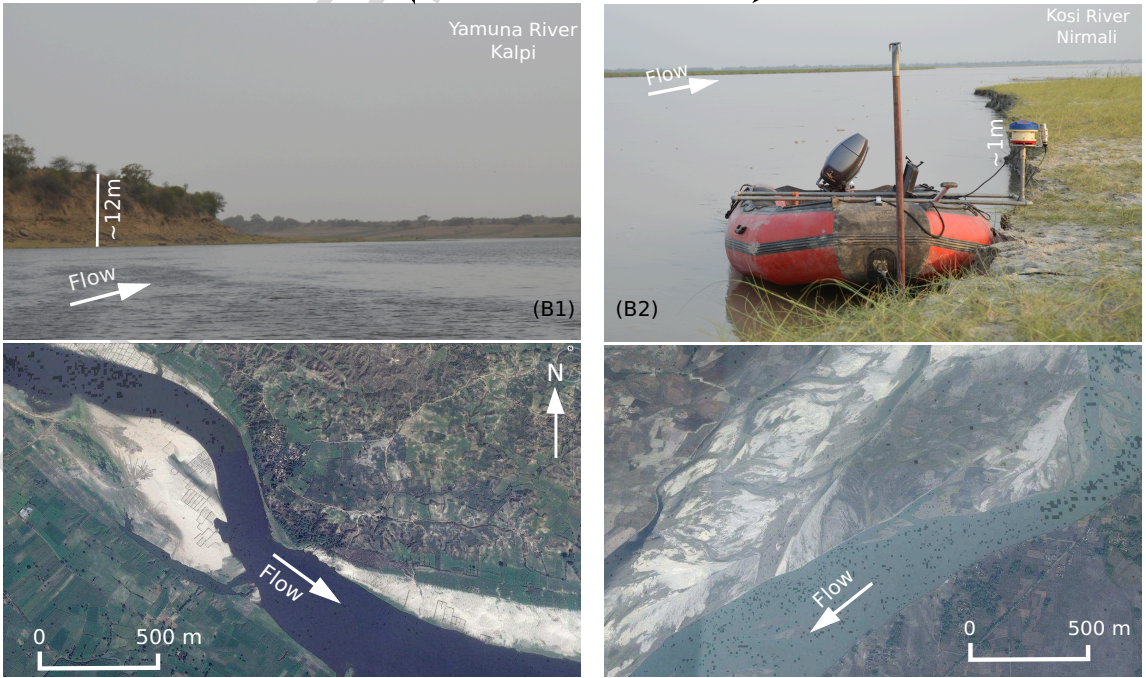

Fig. 2 (A) Map of the Ganga Plain (after Valdiya, 1976); (B) field photographs and corresponding Google Earth images, showing the bed incision of the Yamuna River (B1) near Kalpi and the Kosi River (B2) near Nirmali. 
ing downstream. Finally, mountain-fed rivers originate from the Himalayas where they are fed by monsoon rainfall and snowmelt. Rivers of this type contribute to most of the flow into the Ganga Plain. They are braided and have a large suspended sediment load (an order of about $10^{1}-10^{2} \mathrm{Mt} / \mathrm{yr}$ ) and a large water discharge (an order of about $10^{1}-10^{4} \mathrm{~m}^{3} / \mathrm{s}$ ). Peak discharge is in the Himalayan Foreland during the monsoon from June to October. Monsoon rains contribute about $74 \%$ of the total discharge occurring in the Himalayan Foreland rivers, whereas the remaining $26 \%$ originates from snowmelt (Gohain, 1990; Sinha and Friend, 1994; Gupta, 1997; Latrubesse et al., 2005)

\section{Data and methodology}

\subsection{Measurements}

To establish a width-discharge relationship, we measured the geometry, flow velocity, and grain size of braided and meandering rivers at 98 different locations on the Ganga and Brahmaputra plains (Fig. 3). In doing so, we treat braided rivers as a collection of individual threads. Accordingly, we measured their flow properties and geometry separately (Gaurav et al., 2014; Métivier et al., 2015).

To perform measurements in the field, we first identify river sections that are physically accessible and free from anthropogenic modifications. Then we deployed an Acoustic Doppler Current Profiler (ADCP) on an inflatable motor boat and measured the threads perpendicular to the flow direction. This procedure allowed us to record the depth and flow velocity at regular intervals (cell size $30 \mathrm{~cm}$ ) across a given thread. For each transect, we also collected sediment samples from the surface of its bed. A detailed description 


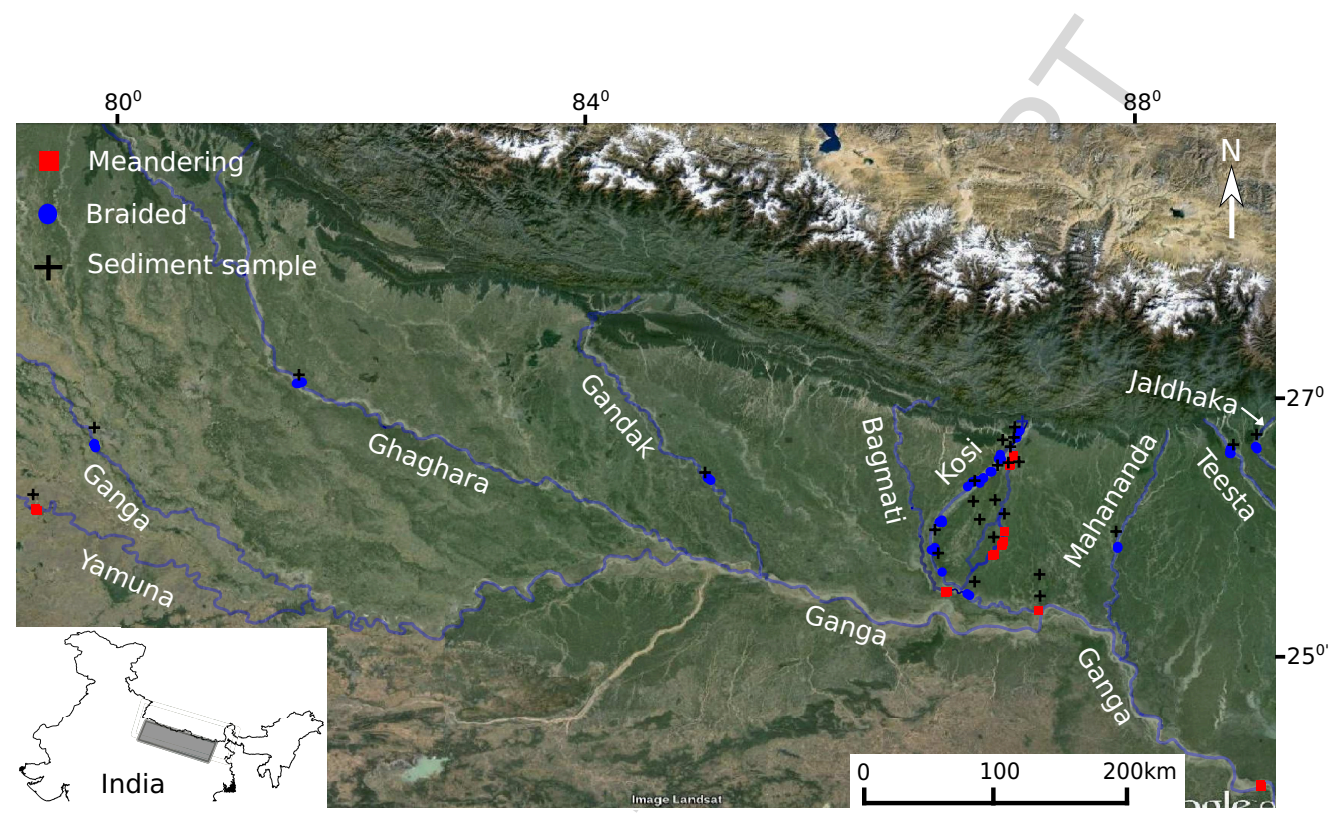

Fig. 3 Locations of hydraulic measurements and sediment sampling sites on the Ganga Plain (source: Google Earth).

of the measurement procedure is given in section 3.2.

\subsection{Thread geometry and velocity profiles}

In field campaigns during the monsoon (July-August) of 2012, just after the monsoon (September-October) of 2013, and before the monsoon (MayJune) of 2014, we levelled 98 transects across the threads from braided and meandering rivers of the Ganga and Brahmaputra plains. This includes 44 transects on the Kosi fan measured in years 2012 and 2013. The remaining transects were measured in the Yamuna (8 transects), Ganga (16), Ghaghara (4), Gandak (5), Bagmati (4), Mahanada (3), Teesta (10), and Jaldhaka (4) rivers in 2014 (Fig. 3).

The thread geometry we measured corresponds to the annual average discharge, which typically occurs between May and October in the Ganga- 


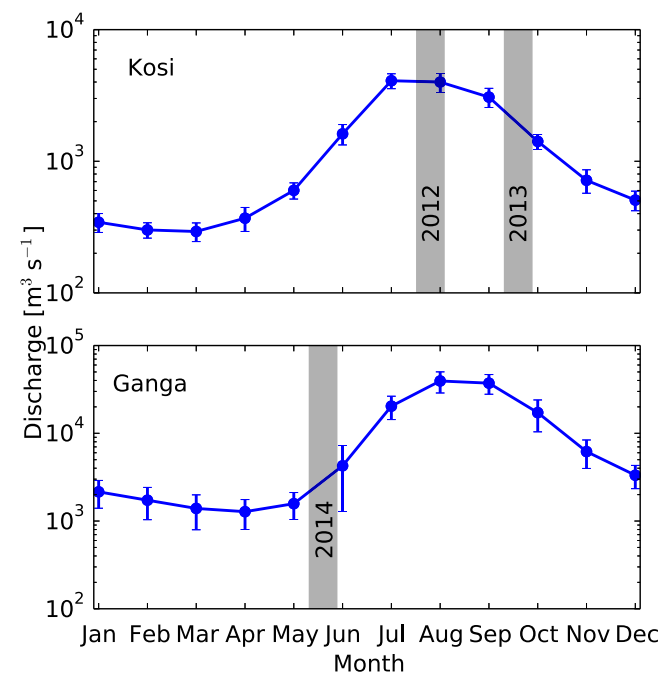

Fig. 4 Average monthly discharge of rivers from the Ganga-Brahmaputra plains. Shaded bars indicate https://daac.ornl.gov/RIVDIS/rivdis.shtml).
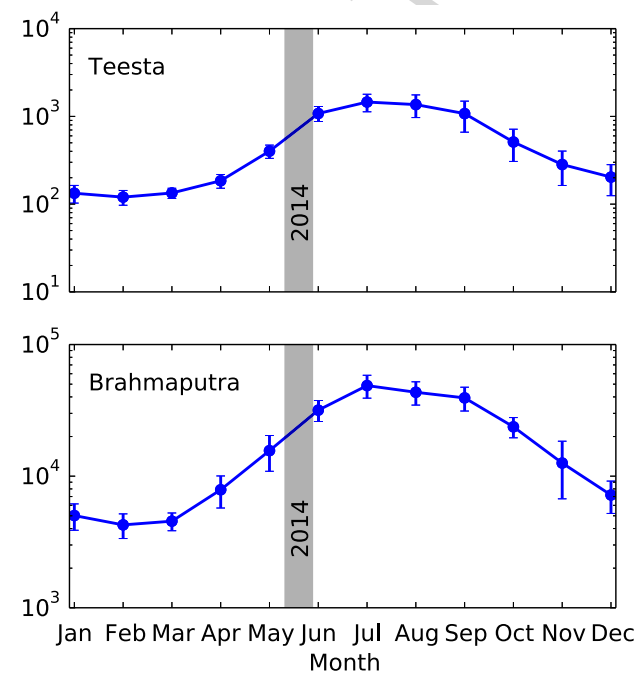

measurement time (data source:

Brahmaputra plains (Fig. 4). This discharge is considered to be the formative discharge (Leopold and Maddock, 1953).

Where the water depth in threads was sufficient $(>1 \mathrm{~m})$, we deployed an Acoustic Doppler Current Profiler (RD-instruments RioGrande 1.2 MHz) to measure their geometry and velocity profile. The ADCP features four transducers with a fixed beam angle of $20^{\circ}$ with respect to vertical (Morlock, 1996; Simpson, 2001; Parsons et al., 2005). It emits acoustic pulses through the water column and records the backscatter from bubbles or sediment particles into equal-size bins of 5 to $25 \mathrm{~cm}$. Based on the Doppler frequency shift of the reflected pulses, it computes the mean velocity of each bin (Rennie and Villard, 2004; Parsons et al., 2005; Chauvet et al., 2014)

To measure the water depth precisely, we supplemented the ADCP with 


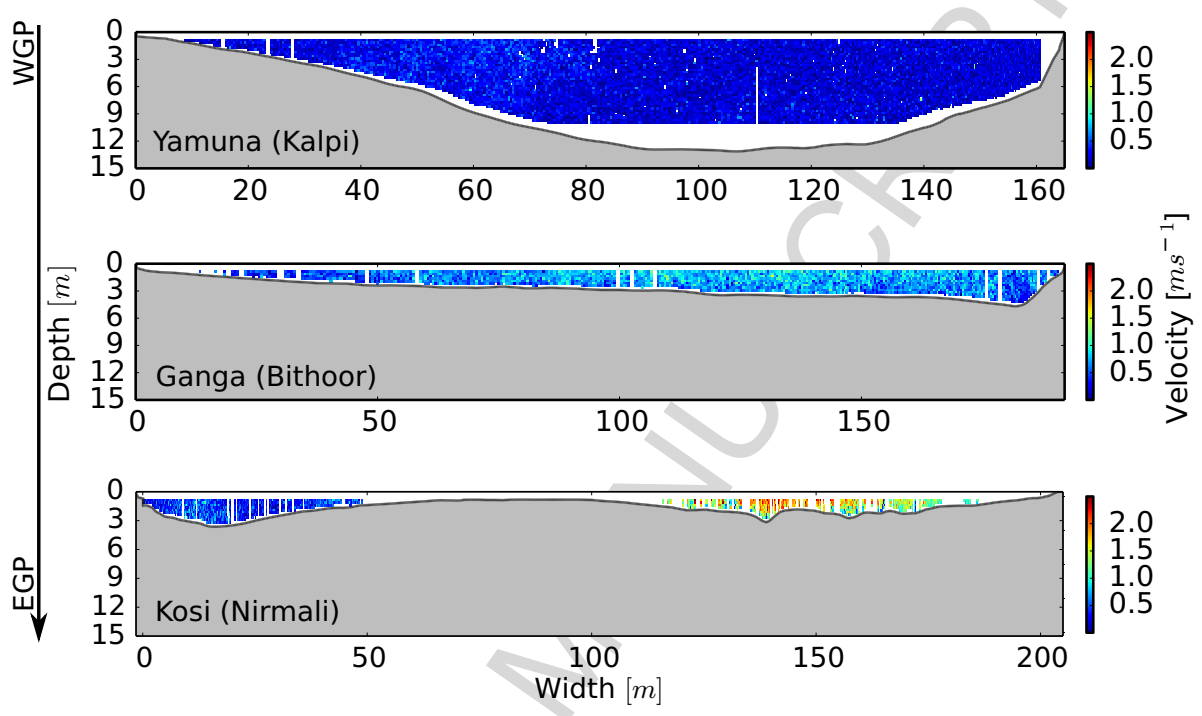

Fig. 5 Velocity profiles measured by ADCP in the channels of western and eastern Ganga Plain rivers.

an external echo sounder (Richardson and Thorne, 2001). In the field, we deployed these instruments on an inflatable motor boat with an additional handheld GPS. The GPS allowed the tracking of the measurement location with a horizontal accuracy of about $10 \mathrm{~m}$. For the geometry and velocity measurements, we crossed the threads perpendicular to the flow direction while the ADCP, echo sounder, and GPS continuously recorded the velocity, flow depth, and location of the transects. We used the ADCP in bottomtrack mode to measure the flow velocity. The discharge passing through the river section was then computed by integrating the streamwise velocity over the cross section (Fig. 5).

To assess the uncertainty of our measurements, we performed at least two consecutive transects at each location. Based on these redundant mea- 
Table 2 Threads, geometries, and discharges measured during our field campaign in the Ganga-Brahmaputra plains.

\begin{tabular}{lcccc}
\hline Threads & $\begin{array}{c}\text { Width }_{(\text {min })} \\
{[\mathrm{m}]}\end{array}$ & $\begin{array}{c}\text { Width }_{(\max )} \\
{[\mathrm{m}]}\end{array}$ & $\begin{array}{c}\text { Discharge }_{(\min )} \\
{\left[\mathrm{m}^{3} \mathrm{~s}^{-1}\right]}\end{array}$ & $\begin{array}{c}\text { Discharge }_{(\max )} \\
{\left[\mathrm{m}^{3} \mathrm{~s}^{-1}\right]}\end{array}$ \\
\hline WGP & & & & \\
Braided & 70 & 700 & 60 & 850 \\
Meandering & 160 & 285 & 85 & 320 \\
\hline EGP+Brahmaputra Plain & & & & \\
Braided & 30 & 1000 & 35 & 2900 \\
Meandering & 30 & 1500 & 8 & 24,500 \\
\hline
\end{tabular}

surements, we then computed a relative error on the mean value of about $10 \%, 15 \%, 5 \%$, and $12 \%$ for width, depth, mean velocity, and discharge respectively. Likely sources of uncertainty include the variability of the boat position and missing ensembles during acquisition. The average flow velocity was calculated from the valid ensembles, which were then extrapolated over the entire cross section to estimate the total discharge. Table 2 reports the statistics of our measurements.

\section{Results}

\subsection{Grain size}

Close to each of the ADCP-measured transects, we collected about 1-2 kg of sediment from the river's bed. We collected these samples on the surface of the left bank, right bank, and bottom of each thread. 


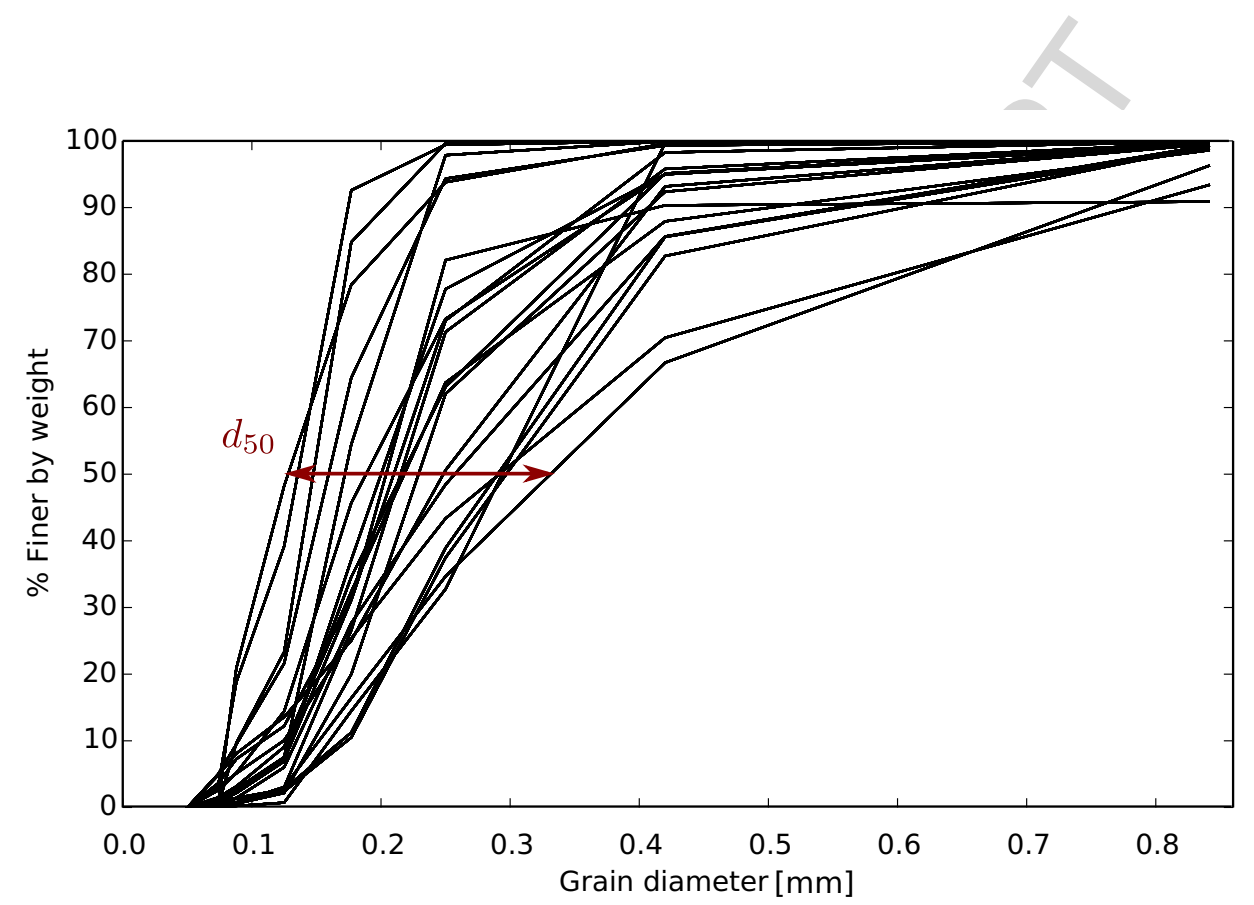

Fig. 6 Grain-size distributions of the river bed sediment for the Ganga-Brahmaputra plains. Arrow: lower and upper limit of the median grain size.

We then sieved these sediment samples in the laboratory into seven categories ranging from 0.074 to $0.841 \mathrm{~mm}$ and calculated their median grain size $\left(d_{50}\right)$ from the resulting distributions. Over the entire Ganga Plain, the median grain size of the river bed sediments ranges from 0.12 to $0.33 \mathrm{~mm}$ (Fig. 6).

\subsection{Thread sinuosity}

The sinuosity index of a river is the ratio of the stream length between two points on the river to the distance between these two points. A straight stream has a sinuosity of 1 , and this number increases as the stream departs from a straight line. Usually a river is considered meandering if it has a 
sinuosity >1.2 (Schumm, 1963; Sinha and Friend, 1994).

To classify a thread as meandering, we calculated its sinuosity. On Landsat 8 satellite image, we identified channels located on the GangaBrahmaputra plains and measured the distance along their path over a distance at least 10 times the average channel width. To assess the influence of the reach distance, we calculated the sinuosity over a distance of 10, 20, 50, and 100 times the average channel width. Finally, we classified threads as meandering where their sinuosity exceeded 1.2 for all measured distances. We classified a river reach as braided if it had more than two intertwined threads.

\subsection{Thread morphologies}

We now compare the morphology of braided and meandering threads to their water discharge. Figure 7 shows the dimensionless width $W_{*}=W / d_{50}$ as a function of the dimensionless discharge $Q_{*}=Q / \sqrt{g d_{50}^{5}}$, where $d_{50}$ and $g=9.81 \mathrm{~ms}^{-2}$ are the median grain size and the acceleration of gravity respectively (Parker, 1979).

As expected, the size of a thread increases with its discharge. We find no clear difference between braided and meandering threads in our data set. Despite considerable scatter (about 1 order of magnitude), all data points tend to gather around a single power law. This observation suggests that, regardless of their planform morphology (braided or meandering), the individual threads of the Ganga and Brahmaputra plains share a common regime relation (Lacey, 1930; Parker et al., 2007). Considering this observation and the earlier finding of Gaurav et al. (2014) and Métivier et al. (2015), we now use the threads of braided and meandering rivers as a single population. 


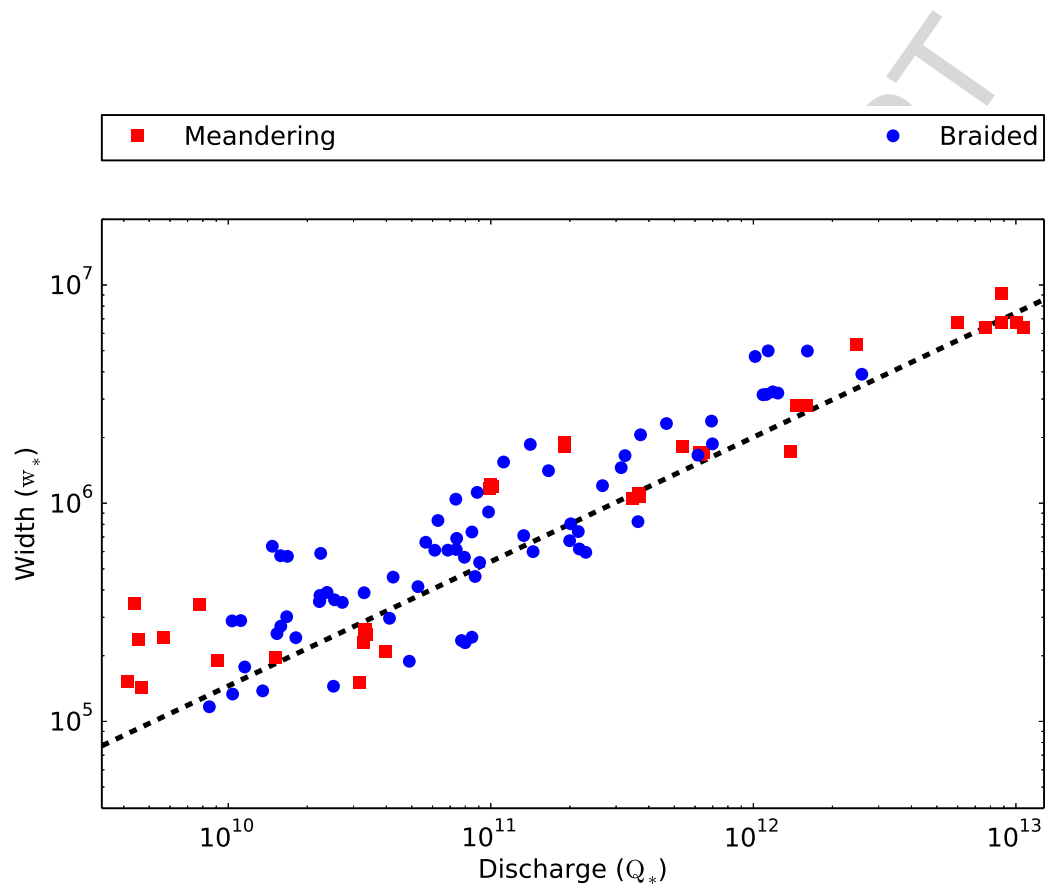

Fig. 7 Dimensionless width $\left(W_{*}=W / d_{50}\right)$ of the threads as functions of the dimensionless water discharge $\left(Q_{*}=Q / \sqrt{g d_{50}^{5}}\right)$. Dashed black line: empirical regime relationships obtained by RMA (see Table 3 for details).

Based on this observation, we perform a reduced major axis regression (RMA) on the logarithm of the width distributions of braided and meandering threads (Table 3). The RMA defines a line of best fit for a bivariate relationship assuming that both variables are measured with errors (Scherrer, 1984; Sokal and Rohlf, 1995; Smith, 2009). The correlations of channel width with discharge are significant $\left(R^{2} \sim 0.83-0.85\right)$ at $95 \%$ level of confidence.

We now evaluate whether the dimensionless width of of meandering threads differ from that of braided threads. To do so, we compute the RMA for these two categories. Table 3 shows that the regime relationship for the threads of braided and meandering rivers of the Himalayan Foreland cannot be differ- 
Table 3 Linear regressions on the $\log _{10}$ of width of the braided and meandering threads as functions of discharge, the confidence level is 95\% (RMA: Reduced major axis regression).

\begin{tabular}{lcccc}
\hline $\log _{10}\left(W / d_{50}\right)=\beta_{w} \log _{10} Q_{*}+\alpha_{w}$ & & & & \\
Ganga Plain & Correlation & $\beta_{w}$ & $\alpha_{w}$ & $R^{2}$ \\
\hline Entire population & RMA & 0.57 & -0.46 & 0.84 \\
Meandering & RMA & 0.53 & 0.01 & 0.90 \\
Braided & RMA & 0.57 & -1.15 & 0.78 \\
\hline
\end{tabular}

entiated at the $95 \%$ level of confidence.

\section{Discussion}

Our results suggest that throughout the WGP, the EGP, and the Brahmaputra Plain the width of the threads of braided and meandering rivers share a common regime relationship. For the Himalayan Foreland rivers, this observation is reported here for the first time. This empirical regime relationship suggests a common physical origin for braided and meandering threads. To explore this hypothesis, we use the regime relations derived from the threshold hypothesis for single-thread alluvial channels (Glover and Florey, 1951; Henderson, 1963; Seizilles et al., 2013). According to this theory, in the absence of sediment transport, sediment particles lying on the channel bed should be exactly at the threshold of motion. The geometry of the channel results from the combination of gravity and flow-induced shear stress. Most rivers of the Himalayan Foreland are active, hence we do not expect the threshold theory to predict exactly our observations. However, now we 
evaluate its ability to predict the scaling of width with respect to water discharge. To do so, we use the threshold theory as a characteristic scale to detrend the channel width with respect to water discharge. This enables us to compare samples from different populations.

\subsection{Scaling laws for the Himalayan Foreland threads}

For a specific discharge, the balance of forces on the bed and banks of a thread at the threshold of motion sets its width, depth, and longitudinal slope. The corresponding regime relations were first derived by Glover and Florey (1951) and Henderson (1963). In dimensionless form, they read (Seizilles, 2013; Gaurav et al., 2014; Métivier et al., 2015, 2016):

$$
\frac{W}{d_{50}}=\frac{\pi}{\mu}\left(\frac{\theta_{t}\left(\rho_{s}-\rho\right)}{\rho}\right)^{1 / 4} \sqrt{\frac{3 C_{f}}{2^{3 / 2} \mathcal{K}[1 / 2]}} Q_{*}^{1 / 2}
$$

where $Q_{*}=Q / \sqrt{g d_{50}^{5}}$ is the dimensionless water discharge (Parker, 1979; Parker et al., 2007; Wilkerson and Parker, 2010). For simplicity, we follow Glover and Florey (1951) and assume that the Chézy friction factor $C_{f} \approx 0.1$ is independent of the flow depth. All other parameters are approximately constant for the threads of the Ganga-Brahmaputra plains: $\theta_{t} \approx 0.3$ is the threshold Shield's parameter, $\mu \approx 0.7$ is the Coulomb's coefficient of friction, $d_{50}$ is the sediment median grain size, $\rho \approx 1000 \mathrm{~kg} \mathrm{~m}^{-3}$ is the density of water, and $\rho_{s} \approx 2650 \mathrm{~kg} \mathrm{~m}^{-3}$ is the density of quartz. Finally, $\mathcal{K}(1 / 2) \approx 1.85$ is the elliptic integral of the first kind.

We then compare our data set to the threshold theory (Fig. 8). The predicted trends accord with the data. However, the threads are wider than predicted by a factor of about 2 . This discrepancy probably reflects the 


- Meandering $\bullet \quad$ Braided

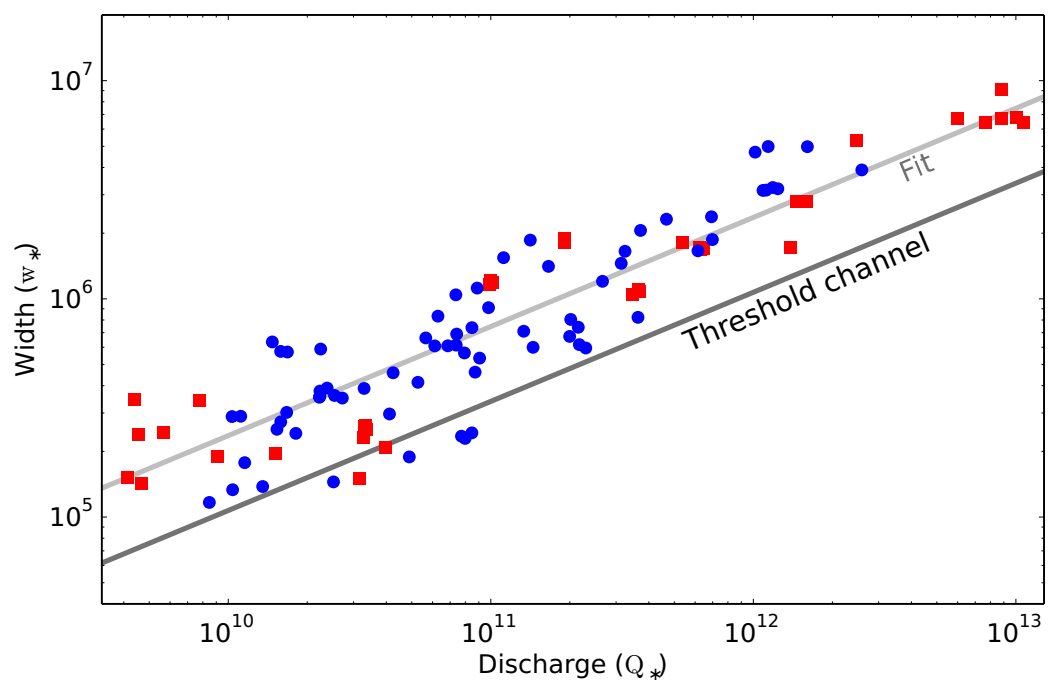

Fig. 8 Width as functions of water discharge. The solid black line corresponds to the threshold theory. The solid grey line is fitted to the data points.

departure from threshold induced by sediment transport. The Ganga River, for instance, transports about $700 \mathrm{Mt}$ of suspended sediments every year (Métivier et al., 1999; Sinha, 2009). However, the threshold theory reasonably predicts the trend of the dimensionless width as the discharge increases (light grey line in Fig. 8), which is obtained by fitting the prefactor of the threshold relation (Eq. 4) to the data while keeping the theoretical exponent. The value of the theoretical exponent $\left(\beta_{w}\right)$ is 0.5 . This value falls within the confidence intervals of an empirical regression. 


\subsection{Detrending}

The semiempirical regime relations based on the threshold theory represent analytically the dependency of width of a thread with respect to discharge. Therefore, we can use them to detrend our data with respect to discharge. To do so, we define the dimensionless width $W_{*}$ as follows:

$$
W_{*}=\frac{W}{d_{50} \sqrt{Q_{*}}}=\frac{W\left(g d_{50}\right)^{1 / 4}}{\sqrt{Q}}
$$

As expected, for meandering and braided threads the dimensionless width depends strongly on water discharge (Fig. 9). Ordinary least square (OLS) regression performed on $W_{*}$ confirms that it is entirely detrended at the $95 \%$ level of confidence. By definition, the logarithms of the detrended width $\left(W_{*}\right)$ is the residual of a linear correlation with the logarithm of discharge. This residual should be normally distributed (Scherrer, 1984; Sokal and Rohlf, 1995). Normal tests confirm this at the $95 \%$ level of confidence (Fig. 9). Based on our data set, the threshold theory therefore explains, at first order, the scaling of width with water discharge.

\subsection{Width of braided versus meandering threads}

Assuming that the dimensionless width $W_{*}$ is independent from the water discharge, we may treat our data set as a sample from a statistically uniform ensemble. Because of the large scatter in our data, this distribution is better expressed in terms of the common logarithm of the parameters.

We find that its mean value and standard deviation are $\left\langle\log _{10} W_{*}\right\rangle \approx$ 0.35 and $\sigma\left(\log _{10} W_{*}\right) \approx 0.2$ for braided threads, and $\left\langle\log _{10} W_{*}\right\rangle \approx 0.36$ and $\sigma\left(\log _{10} W_{*}\right) \approx 0.2$ for single threads. An analysis of the variance shows that these distributions are equivalent for mean and standard deviation. 


\begin{tabular}{|lll|}
\hline- - - & $\bullet$ & Braided \\
--- & & Meandering \\
\hline
\end{tabular}
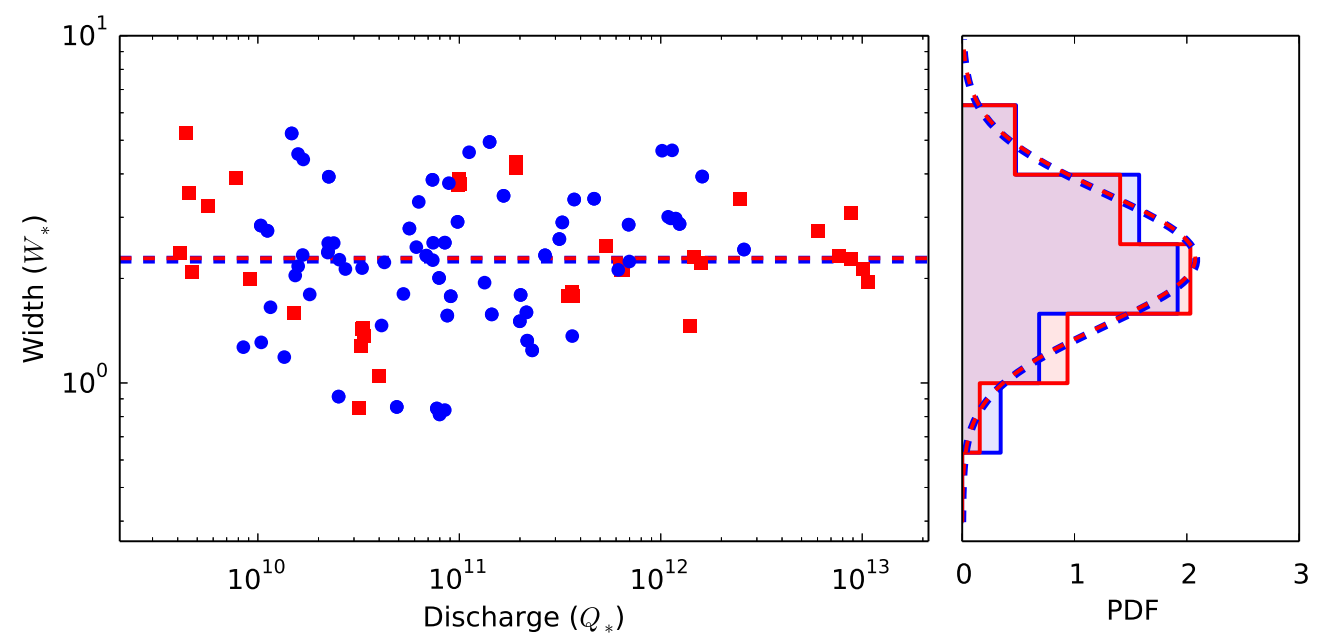

Fig. 9 Left: dimensionless width $\left(W_{*}\right)$ of the Ganga Plain threads as functions of the dimensionless water discharge $\left(Q_{*}\right)$. Dashed blue and red lines indicate averages. Right: corresponding probability density functions.

\section{Conclusions}

The width and discharge of threads of braided and meandering rivers from the Himalayan Foreland, once detrended with respect to discharge, are comparable in size. This observation suggests a common regime relation. This relationship holds for the threads of the Ganga and the Brahmaputra plains of the Himalayan Foreland despite the significant variability of climatic conditions. Its exponent is close to 0.5. This observation accords with the finding of Lacey, who first observed that the width of a single-thread alluvial river scales as the square root of its discharge. We therefore conclude that, at least in our data set, Lacey's law is valid for alluvial braided rivers when 
we decompose them into individual threads. We suggest this finding could apply to other morphological properties and to other places.

Our findings support the use of the threshold theory to scale field measurements. The exponent observed in this study, as well as in previous ones, accords with the threshold theory. This suggests that the physical mechanism that sets the width of single-thread rivers operates in a similar way in braided rivers.

This study points toward the possible existence of universal width-discharge regime relation for braided and meandering rivers worldwide. To evaluate such a relationship, we would need a detailed comparative study for braided and meandering rivers located in different environments worldwide.

\section{Acknowledgements}

We are thankful to all the four reviewers for their detailed comments that helped to improve the manuscript significantly. We thank Morgane Houssais, Hélène Bouquerel and Manudeo Singh for their help in the data collection. K.G and S.K.T would like to thank HoD, Department of Earth and Environmental Sciences and the Director, IISER Bhopal for providing all the necessary institutional supports. Finally, we are grateful to Richard Marston (Editor) for his thoughtful and thorough review of the manuscript.

\section{References}

Ashmore, P., Sauks, E., 2006. Prediction of discharge from water surface width in a braided river with implications for at-a-station hydraulic geometry. Water Resources Research 42 (3). 
Bjerklie, D. M., Moller, D., Smith, L. C., Dingman, S. L., 2005. Estimating discharge in rivers using remotely sensed hydraulic information. Journal of Hydrology 309 (1), 191-209.

Braudrick, C. A., Dietrich, W. E., Leverich, G. T., Sklar, L. S., 2009. Experimental evidence for the conditions necessary to sustain meandering in coarse-bedded rivers. Proceedings of the National Academy of Sciences 106 (40), 16936-16941.

Burbank, D. W., Beck, R. A., Mulder, T., 1996. The himalayan foreland basin. World and regional geology, 149-190.

Chauvet, H., Devauchelle, O., Métivier, F., Lajeunesse, E., Limare, A., 2014. Recirculation cells in a wide channel. Physics of Fluids (1994-present) $26(1), 016604$.

Dhar, O., Nandargi, S., 2000. A study of floods in the brahmaputra basin in india. International journal of climatology 20 (7), 771-781.

Eaton, B., Millar, R. G., Davidson, S., 2010. Channel patterns: Braided, anabranching, and single-thread. Geomorphology 120 (3), 353-364.

Gansser, A., 1964. Geology of the himalayas, 289 pp. Interscience, New York. Gaurav, K., Métivier, F., Devauchelle, O., Sinha, R., Chauvet, H., Houssais, M., Bouquerel, H., 2014. Morphology of the kosi megafan channels. Earth Surface Dynamics Discussions 2 (2), 1023-1046.

Geddes, A., 1960. The alluvial morphology of the indo-gangetic plain: Its 
mapping and geographical significance. Transactions and Papers (Institute of British Geographers), 253-276.

Gleason, C. J., Smith, L. C., 2014. Toward global mapping of river discharge using satellite images and at-many-stations hydraulic geometry. Proceedings of the National Academy of Sciences 111 (13), 4788-4791.

Glover, R., Florey, Q., 1951. Stable channel profiles. Hydraulic laboratory report HYD no. 325, US Department of the Interior, Bureau of Reclamation, Design and Construction Division, 1951.

Gohain, K., 1990. Morphology of the kosi megafan,in: Alluvial fans - a field approach, edited by: Rachocki, a. h. and church, m., 151-178.

Gupta, S., 1997. Himalayan drainage patterns and the origin of fluvial megafans in the ganges foreland basin. Geology 25 (1), 11-14.

Hedman, E. R., Osterkamp, W. R., 1982. Streamflow characteristics related to channel geometry of streams in western United States. Geological Survey Water-Supply Paper 2193.

Henderson, F. M., 1963. Stability of alluvial channels. Transactions of the American Society of Civil Engineers 128 (1), 657-686.

Hirpa, F. A., Hopson, T. M., De Groeve, T., Brakenridge, G. R., Gebremichael, M., Restrepo, P. J., 2013. Upstream satellite remote sensing for river discharge forecasting: Application to major rivers in south asia. Remote Sensing of Environment 131, 140-151. 
Jain, V., Sinha, R., 2003. River systems in the gangetic plains and their comparison with the siwaliks: a review. Current Science 84 (8), 1025-1033.

Lacey, G., 1930. Stable channels in alluvium (includes appendices). In: Minutes of the Proceedings. Vol. 229. Thomas Telford, Proceedings of the Institution of Civil Engineers, Landoon, pp. 259-292.

Latrubesse, E. M., 2008. Patterns of anabranching channels: The ultimate end-member adjustment of mega rivers. Geomorphology 101 (1), 130-145.

Latrubesse, E. M., Stevaux, J. C., Sinha, R., 2005. Tropical rivers. Geomorphology 70 (3), 187-206.

Leopold, L., Wolman, M., 1957. River channel patterns: braided, meandering, and straight. US Government Printing Office Washington (DC).

Leopold, L. B., Maddock, T., 1953. The hydraulic geometry of stream channels and some physiographic implications.

Marcus, W. A., Fonstad, M. A., 2008. Optical remote mapping of rivers at sub-meter resolutions and watershed extents. Earth Surface Processes and Landforms 33 (1), 4-24.

Métivier, F., Barrier, L., 2012. Alluvial landscape evolution: What do we know about metamorphosis of gravel-bed meandering and braided streams? Gravel-Bed Rivers: Processes, Tools, Environments.

Métivier, F., Devauchelle, O., Chauvet, H., Lajeunesse, E., Meunier, P., Blanckaert, K., Zhang, Z., Fan, Y., Liu, Y., Dong, Z., et al., 2015. Morphology of meandering and braided gravel-bed streams from the bayan- 
bulak grassland, tianshan, china. Earth Surface Dynamics Discussions 3, $1289-1316$.

Métivier, F., Gaudemer, Y., 1999. Stability of output fluxes of large rivers in south and east asia during the last 2 million years: implications on floodplain processes. Basin Research 11 (4), 293-303.

Métivier, F., Gaudemer, Y., Tapponnier, P., Klein, M., 1999. Mass accumulation rates in asia during the cenozoic. Geophysical Journal International 137 (2), 280-318.

Métivier, F., Lajeunesse, E., Devauchelle, O., 2016. Laboratory rivers: Lacey's law, threshold theory and channel stability. Earth Surface Dynamics Discussions.

Morlock, S. E., 1996. Evaluation of acoustic Doppler current profiler measurements of river discharge. Water-Resources Investigations Report 954218, US Department of the Interior, US Geological Survey, Indianapolis, Indiana.

Mosley, M., 1983. Response of braided rivers to changing discharge. Journal of hydrology. New Zealand 22 (1), 18-67.

Parker, G., 1979. Hydraulic geometry of active gravel rivers. Journal of the Hydraulics Division 105 (9), 1185-1201.

Parker, G., Wilcock, P. R., Paola, C., Dietrich, W. E., Pitlick, J., 2007. Physical basis for quasi-universal relations describing bankfull hydraulic geometry of single-thread gravel bed rivers. Journal of Geophysical Research: Earth Surface (2003-2012) 112 (F4). 
Parsons, D., Best, J., Orfeo, O., Hardy, R., Kostaschuk, R., Lane, S., 2005. Morphology and flow fields of three-dimensional dunes, rio paraná, argentina: Results from simultaneous multibeam echo sounding and acoustic doppler current profiling. Journal of Geophysical Research: Earth Surface (2003-2012) 110 (F04S03).

Pavelsky, T. M., 2014. Using width-based rating curves from spatially discontinuous satellite imagery to monitor river discharge. Hydrological Processes 28 (6), 3035-3040.

Rao, M. R., 1973. The subsurface geology of the indo-gangetic plains. Geological Society of India 14 (3), 217-242.

Rennie, C. D., Villard, P. V., 2004. Site specificity of bed load measurement using an acoustic doppler current profiler. Journal of Geophysical Research: Earth Surface (2003-2012) 109 (F3).

Richardson, W. R., Thorne, C. R., 2001. Multiple thread flow and channel bifurcation in a braided river: Brahmaputra-jamuna river, bangladesh. Geomorphology 38 (3), 185-196.

Scherrer, B., 1984. Biostatistique. Chicoutimi, Québec: G. Morin.

Schumm, S. A., 1963. Sinuosity of alluvial rivers on the great plains. Geological Society of America Bulletin 74 (9), 1089-1100.

Schumm, S. A., Mosley, M. P., Weaver, W., 1987. Experimental fluvial geomorphology.

Seizilles, G., 2013. Forme d'équilibre d'une rivière. Ph.D. thesis, Paris 7. 
Seizilles, G., Devauchelle, O., Lajeunesse, E., Métivier, F., 2013. Width of laminar laboratory rivers. Physical Review E 87 (5), 052204.

Simpson, M. R., 2001. Discharge measurements using a broad-band acoustic Doppler current profiler. US Department of the Interior, Open-File Report 01-1, US Geological Survey, USGS, Sacramento, California,.

Singh, I. B., 1996. Geological evolution of ganga plain-an overview. Jour. Palaeontological Soc of India 41, 99-137.

Sinha, R., 2009. The great avulsion of kosi on 18 august 2008. Current Science $97(3), 429-433$.

Sinha, R., Friend, P. F., 1994. River systems and their sediment flux, indogangetic plains, northern bihar, india. Sedimentology 41 (4), 825-845.

Sinha, R., Jain, V., Babu, G. P., Ghosh, S., 2005. Geomorphic characterization and diversity of the fluvial systems of the gangetic plains. Geomorphology 70 (3), 207-225.

Smith, C. E., 1998. Modeling high sinuosity meanders in a small flume. Geomorphology 25 (1), 19-30.

Smith, L. C., Pavelsky, T. M., 2008. Estimation of river discharge, propagation speed, and hydraulic geometry from space: Lena river, siberia. Water Resources Research 44 (3).

Smith, R. J., 2009. Use and misuse of the reduced major axis for line-fitting. American Journal of Physical Anthropology 140 (3), 476-486. 
Sokal, R. R., Rohlf, F. J., 1995. Biometry: the principles of statistics in biological research. New York, NY: WH Freeman and Co.

Tal, M., Paola, C., 2007. Dynamic single-thread channels maintained by the interaction of flow and vegetation. Geology 35 (4), 347-350.

Valdiya, K., 1976. Himalayan transverse faults and folds and their parallelism with subsurface structures of north indian plains. Tectonophysics 32 (3-4), $353-386$.

Wilkerson, G. V., Parker, G., 2010. Physical basis for quasi-universal relationships describing bankfull hydraulic geometry of sand-bed rivers. Journal of Hydraulic Engineering 137 (7), 739-753. 